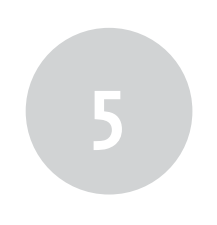

\title{
THE DIPLOMACY OF THE TWO STANDARDS
}

\section{THE NATURE OF POLITICAL ACTION}

Our fourth axiom is that the starting position for political deliberation is inevitably non-ideal. We act always under constraint. What cannot be pictured now can become possible, given the right intermediate steps. Our fifth axiom, conceived against this background, is that discernment in the midst of opacity in accordance with a common standard should become a core value in the conduct of international relations. Our axioms are congruent with Amartya Sen's (2010) idea of justice. Sen calls for 'ways of judging how to reduce injustice and advance justice', even when we find it difficult to characterise 'a perfectly just arrangement' (Sen, 2010, pp. ix, 21). Whether at the global level or within nation states, 'a perfectly just arrangement' is beyond our reach, all the more so at a time of rapid change. Our axioms are also congruent with the relation between the 'Small Tranquillity' and 'Grand Union' in the Confucian worldview (Chan, 2014, p. 9). In discerning a way forward under unfavourable conditions, we accept lesser measures reflecting a lesser ideal (the Small Tranquillity) while keeping a higher vision (the Grand Union) in play as a guiding standard or 'regulative ideal'. 


\section{OUR FOURTH AXIOM: THE STARTING POSITION FOR POLITICAL DELIBERATION}

\section{BEING MORE: POLITICS AS TRANSITION}

As a matter of experience, and in many religions as a matter of doctrine, any political dispensation is flawed and capable of improvement. Legitimacy does not mean perfection. Development - being more - is always a dimension of personal and public life. The practice of politics is a journey from an inherited situation, which in the nature of things is defective or deficient, towards a more just order. The concept of a 'just transition' underlies the SDGs, the 'greening' of the global economy, and now, also, emerging national economic strategies in the light of COVID-19.

The idea of a 'just transition' can draw on our first axiom, concerning the difference between abstract ideas and a penetrating, personal knowledge of situations, and their reality as lived; we need new research across several disciplines if the inevitable changes in our economic model are to reduce vulnerabilities and not make them worse.

A 'just transition' can draw also on our second axiom, concerning the 'ideal' that helps shape the 'real' and the imaging of peace. The challenge is to enable our 'pre-political' understanding of the good to shed light on each new set of circumstances.

In shaping our changing circumstances, we need to draw on our third axiom as well and take into account the factors that accompany healing in a wounded social structure. Nature and human society are not simply 'there', awaiting our choices. Complex connections are already in place and in play. Our interventions can disrupt balances and break connections. At a minimum, we must 'do no harm'. Our proper goal is to uncover the sources of benign change.

\section{ENDS AND MEANS}

Using a metaphor from archery, Aristotle states that virtue enables us to 'hit on' the mean (arete ... stochastike tou mesou), where the 'mean' is the right option among alternatives (Nicomachean Ethics, II.6). This virtue is, precisely, 'pre-political'; it includes an intimation 
of 'noble and divine things' (Nicomachean Ethics, X.7.1). We often forget that modern multilateral diplomacy, as conceived in response to the Holocaust and the horror of world wars, has this Aristotelian quality; it would not exist without a set of higher values to inform individual choices.

The first words of the Preamble to the UN Charter ${ }^{1}$ are as follows:

We the peoples of the United Nations, determined to save succeeding generations from the scourge of war.

Further high-level 'ends' are defined in the opening paragraphs of the Preamble. 'The peoples of the United Nations' are determined:

To employ international machinery for the economic and social advancement of all peoples.

Article 1 states that among the purposes of the Charter is:

To be a centre for harmonizing the actions of nations in the attainment of these common ends.

A similar pattern is present in the Universal Declaration of Human Rights (UDHR). ${ }^{2}$ Article 1 states the following:

All human beings are born free and equal in dignity and rights. They are endowed with reason and conscience and should act towards one another in a spirit of brotherhood.

Article 28 relates human dignity to life in community:

Everyone is entitled to a social and international order in which the rights and freedoms set forth in this Declaration can be fully realized.

Articles 1 and 28 are the scaffolding on which the detailed provisions of the Universal Declaration rely; these provisions, and each subsequent decision in support of human rights, go back to questions of human origins and destiny.

\section{THE GAP BETWEEN IDEAS AND REALITY}

In the 21st century, the creative interplay of ends with means is frustrated by a widening gap between ideas and reality in at least three domains. 
First, we need to re-imagine the 'Westphalian' system understood as a world order based only on the 'sovereign' decisions of nation states. The states' equal right to sovereignty does not preclude the development of new forms of socio-political organisation such as the European Union or the acceptance of 'citizenship obligations' (Haass, 2017) at the regional or global level. In the realm of national governance, our actions, to have a strong ethical foundation, need to take into account their foreseeable consequences for external stakeholders and for the common good. In this respect, political practice is behind the times. National governments, even when they grasp the need for a global dimension to policy, remain fearful of unilateral steps that may hand an advantage to other, more selfish actors. Equally, political theory is behind the times. The 'separation of powers' and other balancing devices do not, in our view, confer an absolute legitimacy on governments under today's conditions, absent a concomitant commitment to international justice and morality.

Second, in the realm of the economy, we need a clearer understanding of the relationship between profit and not-for-profit factors in our individual decision making and in shaping the marketplace at home and abroad. The COVID-19 crisis has demonstrated more clearly than ever that 'GDP' is an inadequate measure of value and as currently deployed exacerbates the problem of 'limited coverage' in the ethical sphere, which we discussed in Chapter 2.

Third, the problem of 'limited coverage' arises in an acute form as we pursue a deeper understanding of the increasingly important subject of migration. The rights of migrants are often not respectedor even well understood - within our current political economy.

In relation to these fundamental challenges - the interpretation of sovereignty under 21st-century conditions, our conceptions of economic freedom and economic productivity, and the principles that should govern migration - we are surviving from day to day, if we are honest, in a house that is badly in need of renovation. Add to this confusion our unpreparedness on environmental issues, and in 2020 the lessons of the COVID-19 pandemic, and the flimsiness of our dwelling place amounts to a crisis.

Very often, our difficulty in relating means to ends, and understanding the innate character of our decisions, hinges on a too narrow reading of the context. Even apart from the 'structural' sources 
of confusion, which we have just mentioned, we find it difficult to connect the situation immediately in front of us with 'what we should consistently be doing' in the light of 'the society all of us want' (Milbank and Pabst, 2016, p. 4). Below, we offer four examples of seemingly legitimate choices that become more uncomfortable the more we reflect on their implications in a wider context.

\section{Example one}

In a society in which the public health service has long waiting lists or may hardly function at all, I ensure that my own family has private health insurance. Should I ask myself whether such a choice, habitual among better-off people, slows down the development of adequate services for everyone? If the answer is 'yes', is there a way forward that enables me to protect my family while working towards the objective of universal access to healthcare?

\section{Example two}

A leading democratic society sells weapons into a country in which malnutrition or other human rights abuses are widespread. How legitimate is the argument, 'If we don't sell the arms, someone else will'?

\section{Example three}

My 'lifestyle', if I belong to the upper-middle class in a 'developed' country, can never be 'universalised' because the resources of the planet will not permit everyone in India (for example) to live as I do. Is there a moral inconsistency in my life stance? If I see an inconsistency, is it because of the principle of burden-sharing during a necessary transition, or for deeper reasons?

\section{Example four}

Historically, a very common situation is that a soldier or public official has misgivings about the context in which he works - an aggressive war, a military strategy under which planning is going forward for the use of weapons of mass destruction, a colonial administration 
in the midst of a popular uprising, a corrupt or dictatorial government, or simply a government wedded to dangerous policies. In the light of his own successful career under Domitian, Tacitus insists that a man can do great good under a bad prince (De Vita Agricolae, 42). Who would dare to say that this is not so?

\section{THE FOCUS OF OUR POLITICAL ATTENTION}

Our understanding of our responsibilities depends to a considerable degree on our vantage point. One way of looking at the world of geopolitics is to focus on the 'objective power' of certain actors (Rudd, 2020, p. 3):

As with other historical inflection points, three factors will shape the future of the global order: changes in the relative military and economic strength of the great powers, how those changes are perceived around the world, and what strategies the great powers deploy.

This could be described as the view from the general's tent. Many of those who view the world through the flap of this tent (though not the author of the passage just quoted) are open to harsh measures. In the 'post-post-Cold War' period, a very senior British diplomat wrote as follows under the headline 'Why we still need empires':

When dealing with old-fashioned states outside the post-modern continent of Europe, we need to revert to the rougher methods of an earlier era - force, pre-emptive attack, deception, whatever is necessary ... Among ourselves we keep the law but when we are operating in the jungle, we must also use the laws of the jungle. (Cooper, 2002, n.p.)

In seeking to illuminate the moral compromises that accompany political action, Machiavelli does not deny the importance of moral values as the glue of society. However, in The Prince, he argues that the ruler must learn 'how not to be good' on certain well-chosen occasions. Deceit, and even cruelty, are justified by results - by their effect as measured over time - which requires very sharp judgement by the prince if his recourse to realpolitik is not to undermine the moral standards of 'ordinary people'. Max Weber appears to entertain a similar paradox in his thesis that politics is a vocation (Beruf) that requires a good man to leave his preferred values behind (Walzer, 1973). 
The structure of these arguments is echoed in many of our contemporary discussions of torture, assassination, drone warfare, and the past and possible future use of weapons of mass destruction. We risk finding ourselves in the company of Julius Caesar who, as we saw in Chapter 2, could cut off the hands of his military opponents in the belief that it did not detract from his image or character.

The discourse around realpolitik and its supposed necessities contributes little to our understanding of everyday trade-offs and compromises as we seek to do good under a 'bad prince' or within a somewhat dysfunctional economy.

We suggest a different line of vision, more like that of the 'doomed, conscripted, un-victorious ones' (Siegfried Sassoon) than the view from the general's tent. Within our chosen line of vision, we see nation states that enjoy 'objective' power and influence but fall short in addressing public health issues, the protection of the environment, and other basic needs of citizens. Their conception of security and legitimacy is at a remove from the reality of people's lives. In the long run, their power to control events is likely to prove illusory, unless they examine the patterns of their behaviour in the light of all that they ought to know and can know, and set their course in a new way. In suggesting this, we do not ignore the view from the general's tent. On the contrary, we seek to engage with it by insisting on a broader focus of attention.

In early Indian legal theory, the term matsyanyaya ('fish-justice') describes a world in which the big devour the small, irrespective of the high-level rules of society (Sen, 2009, p. 20). In Roman law, there is an obligation to act in good faith, ex bona fide: we should not take advantage of the weak position of our partners in a transaction (Cicero, De Officiis, III.15, 17). When others live in squalor and have no way of sharing their talents with the community, and we have the ability to change this and do not do so, can it be said that we exercise our citizenship with an abundance of good faith? Or have we opened the doors of our world to matsyanyaya - to 'fish-justice'?

Our fourth axiom focuses on the shared predicament of all of us, including powerful leaders, once we acknowledge that our way of living and acting is troubling in the light of our own best insights or the concerns expressed to us by others. When society is open to positive change, 'the underlying theme in the conversation is not conflict, it is agency’ (Nyabola, 2018, p. 215). 
Aristotle's thinking on 'mixed actions' seems to us to clarify the choices that arise once we recognise that the starting position for political deliberation is inevitably non-ideal. In particular, Aristotle clarifies the choices Machiavelli is grappling with when he advocates 'not being good', and Weber when he refers to 'the demon' that affects politics as a profession. These dilemmas, which are similar to the 'problem of dirty hands', posed by Jean-Paul Sartre in the second half of the 20th century, become a subset of the much wider problem that we act at all times within the constraints of a given situation. Humanity's future will not be secured by 'dirty hands'. It can be secured only by engaging constructively with difficult situations. We live with imperfection. We navigate the non-ideal as best we can.

Aristotle's conception of 'mixed actions' is rooted in political, as well as personal, experience.

Solon, the first great constitutional reformer at Athens, is summoned as an arbitrator when social divisions threaten the disintegration of society. The worst single aspect of the situation is the practice of enslavement for debt; Solon brings this to an end. For the rest, he does not start with a blank slate or build a settlement from scratch. His complex package of reforms to an extent reflects the existing balance of power between rich and poor as broad categories within society. No one is perfectly happy with the proposed reforms. But neither is any powerful group so discontented as to risk conflict by trying to overturn the settlement. Solon operates creatively within the de facto limits on his freedom of action. He describes this in a poem as 'finding the right fit between justice and force' (quoted in Aristotle, Athenian Constitution, XII.4).

For Aristotle, Pericles exemplifies the leader who can relate concrete decisions to an overall vision. In the narrative of Thucydides, Pericles sees the contradiction between the world that might be and the facts facing him, between 'pre-political values' and constrained political choices. Here is a key passage from Pericles' final speech (Thucydides, 1996, II.61.1): 'For those who have a free choice in the matter and whose fortunes are not at stake, war is the greatest of follies.'

Aristotle echoes Thucydides (Nicomachean Ethics X.7.6): 'No one chooses to be at war ... for the sake of being at war.'Thucydides has 
an epigrammatic phrase to describe situations of this kind: men 'fall, without willing it, into severely limiting circumstances' (III.82:2).

Building out from the experience of leaders like Solon and Pericles, Aristotle develops the doctrine of what he terms 'mixed actions' - understandable actions that are both unfree and free because they arise within the constraints of a given situation (miktai praxeis: Nicomachean Ethics III.1; Eudemian Ethics II.8). Covering some of the same ground as Aristotle, but with less clarity, Cicero (De Officiis III.2) addresses the question of 'how we should make a moral discernment if that which seems morally right (honestum) is in conflict with what seems expedient (utile)'.

A 'mixed action' is by definition an uncomfortable choice: 'Actions of such a kind are voluntary, but in an ultimate sense, perhaps non-voluntary; for the reason that no one would choose any of these things for its own sake' (Nicomachean Ethics, III.1.6).

Aristotle considers the case of a storm at sea. If I throw my possessions overboard during a storm to save the ship from sinking, I am doing something I would never 'choose' to do, other things being equal; to that extent my action is unfree. In another perspective, throwing the goods overboard is something I decide to do; to that extent, I am acting freely. What seems justifiable, namely, to ditch the cargo, does not seem 'just' in the full sense of the word.

Aristotle presents a number of other instances of 'un-willed' action; for example, the actions of those who are drunk, or overpowered by others, or ignorant of the law. But to grasp what is meant by 'mixed action' in a political situation, it is important not to lose our way in a specialised discussion among philosophers about 'intention' and 'freedom of the will'. Agamemnon's decision, famous in Greek mythology, to kill his daughter Iphigenia to secure a fair wind for Troy, is a 'mixed action' - a political choice made under obvious duress. The issue is whether it can be justified; Iphigenia's death is not the outcome of a sudden emotional storm, nor is it the unintended secondary effect of a different decision. The question that confronts Agamemnon is whether it is right to accept a political premise and a public responsibility which 'force him' (as he thinks) to do a terrible thing. In such circumstances, should there not be an option to invoke 'the moral equivalent to our legal right not to incriminate ourselves' (Walzer, 1973, p. 165)? 


\section{PARAMETERS FOR MIXED ACTION}

The challenge for political philosophy is to set parameters for 'mixed action' so that we do not end up with a Machiavellian acceptance that it is 'right to do wrong' or endorse Weber's portrait of the relentless, 'objective' leader who in choosing politics 'loses his soul' (Walzer, 1973, p. 177). We suggest five parameters for the evaluation of 'mixed action'.

\section{Recognising the enormity of certain actions}

First, some actions are ruled out by their very nature. There is a Confucian principle, 'we should not execute a blameless man even to gain an empire'. 'The things that forced Euripides' Alcmaeon to slay his mother seem absurd' (Nicomachean Ethics, III.1.8). We have suggested in earlier chapters that a sense of reverence or hesitation should hold us back from the 'enormity' of certain actions. Cicero twice rejects the long-term strategic argument used by the Romans to justify the destruction of Corinth ('nollem Corinthum': De Officiis, I.11; III.11). Not to tell lies or to make contradictory promises would seem to be a rule of peace-building that we should never set aside.

\section{Proportionality}

Second, it is not hard to see that proportionality is a condition of any justifiable mixed action. By way of establishing the criterion of proportion, Aristotle mentions a man who kills his opponent in anger for bumping into him in a game of blind man's bluff. Ideas of measure and proportion run through all law and every study of virtue. We can see the case for, say, avoiding sugary drinks or reducing our dependency on private motor vehicles. To ban these things altogether would be a disproportionate measure. We can promote the global public interest in the development, production, and distribution of vaccines without disregarding the interests of researchers and companies; a successful policy is likely to reflect a sense of proportion.

\section{Motive}

A third parameter, a leitmotif in the narrative of Thucydides, is the need to look carefully at our motives. Often, a supposedly reluctant 
decision of last resort is not, in reality, based on the impartial weighing of options in the midst of opacity. Rather, we act by force of habit, under the influence of anger or jealousy, with a view to bolstering our power for the future, or in furtherance of a self-image that blinds us to the truth of what we are doing. It would be instructive to review the best known military interventions of the 21st century from a Thucydidean angle.

\section{Leaving space for ordinary life}

Fourth, we should not allow our search for a better future to blunt our appreciation of the imperfect present. Engagement with our responsibilities is essential: to analyse every small step, or tremble all day long in fear of the consequences of what we may or may not decide to do, seems neither wise nor productive. Moments of relaxation or celebration are a part of life.

The story of the woman who poured ointment on the feet of Jesus is told differently in each of the four gospels. In St John, Judas Iscariot complains about the waste of money - according to St John, because of his corrupt management of the disciples' common fund. Jesus defends the woman's gesture as having intrinsic value, here and now, especially in the perspective of his own coming death.

Dietrich Bonhoeffer wrote the following to his fiancée in a letter from prison in March 1944 (Bonhoeffer and von Wedemeyer, 1994, p. 169):

It's precisely because I'm already so certain of our agreement on fundamentals that we've no need to discuss the mysteries of existence all the time, but can take things as they come and continually rediscover each other in the ordinary things of life. There will be times when we're drawn to fundamentals of our own accord, but God subsists not only in fundamentals but in everyday life as well.

\section{Overcoming the circumstances and mitigating} the effects of a mixed action

Our fifth parameter is this: to the degree that we defend an action as 'mixed', as an unavoidable response to unwelcome circumstances, we are under a corresponding consequential obligation (i) to work towards overcoming the conditions that impose the necessity; and 
(ii) to mitigate as much as we can the suffering caused by our action. Unless we accept such obligations, our claim to have acted under constraint is not believable.

A textbook illustration of what we mean by 'overcoming the conditions' is provided by the Nuclear Non-Proliferation Treaty (NPT). ${ }^{3}$ Nuclear deterrence is not a strategy that we choose for its own sake. If, nevertheless, international law allows the possession of nuclear weapons by some states (an interpretation that can be disputed), that is at best a 'mixed action' on the part of the international community, something accepted under the duress of circumstances. The legitimacy of this 'mixed action' depends on a corresponding forward-looking obligation on the nuclear weapons states to work towards overall nuclear disarmament (NPT, Article VI).

To illustrate what we mean by 'mitigating the suffering' caused by a mixed action, we turn to the prison system. Deprivation of liberty is a severe punishment that can be defended as a mixed action. In practice, imprisonment is often accompanied by family breakdown, risks to health and safety, and a lifelong loss of earning capacity. According to our fifth parameter, a legitimate prison policy should seek to mitigate these 'non-necessary' consequences of imprisonment. It should also promote alternatives to imprisonment - not least because the much lower incidence of imprisonment in some social groups than in others calls into question the inherent 'necessity' of the system.

Just before his execution, Helmuth von Moltke, the leader of the Kreisau Circle, ${ }^{4}$ wrote these words to his son (Ashdown, 2018, p. 289):

Since National Socialism came to power, I have striven to make its consequences milder for its victims and to prepare the way for a change. In that, my conscience drove me - and in the end, that is a man's duty.

\section{ST PAUL AND MIXED ACTION}

St Paul's response to the question of chattel slavery - that most embedded and most profound of structural injustices - can be understood as a case study in 'mixed action', as applied to a wounded social structure. In a morally compromised situation, St Paul, like von Moltke, strives to make the consequences milder for victims and to prepare the way for change. 
In St Paul's time, there was much discussion of slavery and the treatment of slaves among philosophers and jurists. Paradoxically, the growing jurisprudence around some aspects of slavery, including rules for manumission, had the overall effect of embedding the institution still more deeply in Roman life. Nor was it practicable to overthrow the Roman social system by direct action, as the fate of Spartacus illustrates.

In Roman history, the most significant (and humane) author on the topic of slavery is St Paul's contemporary, Seneca (Griffin, 1976; Finley, 1980; Garnsey, 1996). St Paul encountered the world of Seneca directly. The governor of Achaea who chose to overlook St Paul's missionary activity (using arguments that Pilate may initially have sought to use in the case of Jesus) was Seneca's respected older brother Junius Gallio Annaeanus (Acts 18). Seneca was still a key advisor to Nero when St Paul 'appealed to Caesar' (though within five or six years, both Gallio and Seneca, like St Paul, had fallen victim to the Emperor Nero's repressions).

Both Seneca and St Paul regard slavery as an institution 'against nature'. St Paul improves on the 'progressive' consensus of his time in three main ways.

\section{Prescinding from the 'back story'}

There was a well-known Stoic paradox, 'Every good man is free, every bad man is a slave'. On this view, both masters and slaves should accept the workings of 'chance', or 'fortune', or 'fate', and concentrate on self-development.

Jesus has no interest in 'fortune', 'fate', or any back story to explain disability:

Rabbi, who sinned, this man or his parents, for him to have been born blind?

Neither he nor his parents sinned. He was born blind so that the works of God might be displayed in him. As long as the day lasts, I must carry out the work of the one who sent me.

(John 9:1-5; cf. Luke 13:4-5 on those killed by the collapse of a tower)

Because the teaching of Jesus is forward-looking in this way, St Paul has the room he needs to treat the situation of master and slave as 
'given' only in a contingent sense. There is no 'back story' that entitles a slave-owner to act as he sees fit within the limits of his role.

The opening passage of Aristotle's Politics differentiates among human beings in terms of three basic distinctions: man/woman, master/slave, and Greek/barbarian. St Paul implicitly challenges Aristotle. In Galatians (3:27-28), he rejects, in the name of Christ, the dichotomies male and female, master and slave, Jew and Greek. In Colossians (3:11), St Paul adds that there is no 'barbarian, Scythian, slave'. Similar arguments are presented in the First Letter to the Corinthians (12:13) and (minus the listing of categories) in other letters.

\section{Speaking directly to slaves}

Seneca writes as one 'humane' slave-owner to another, especially in a famous letter to his friend Lucilius (Seneca, 1917, Epistula XLVII, pp. $301-313)$. St Paul's communications on slavery are intended to be heard by both slave and master.The First Letter to the Corinthians includes the following messages (7:20-24):

If you can gain your freedom, take the opportunity.

Do not become the slaves of men.

(Verse 21)

(Verse 23)

This whole passage is governed by the qualification, 'this is from me and not from the Lord' (7:12). St Paul offers prudential advice.

\section{Taking a forward-looking view}

The Passover commemorates a release from slavery (Ochs, 2020). The language of redemption in the New Testament suggests the payment made to a slave-holder to secure the freeing of a slave (lytron: Hart, 2017, p. 556). John the Baptist, Jesus, and their disciples do not themselves own slaves. The episode in which Jesus washes the feet of the disciples is emblematic in this respect (John 13:3-18). St Paul's Letter to Philemon is the only part of the New Testament devoted entirely to a contemporary issue in Roman law. It is an open communication that is clearly intended to have 'demonstration value'.

The Letter does not acknowledge an obligation to send the slave Onesimus back to his master; on the contrary, St Paul openly contemplates not sending him back (verses 13-14). Legally and 
politically, St Paul is treading on dangerous ground. Is he encouraging slaves to run away?

St Paul's solution to this 'micro' situation of considerable delicacy goes further than an appeal to the sophistication and virtue of the slave-owner. Paul seeks an assurance from Philemon that Onesimus, if he returns, will no longer be treated in the usual way, as a slave would be liable to be treated under Roman law and custom: "not as a slave any more, but something much better than a slave, a dear brother' (verse 16).

As mentioned in Chapter 4, St Paul describes himself as the koinonnos of both Philemon and Onesimus (verse 17); he is 'in communion with' both. This, we have suggested, takes the Greek political concept of a 'shared life' in a new direction. The 'shared life' of master and slave in one well-advertised case will have consequences at the 'macro' level for anyone who pauses to reflect - consequences for sexual access to slaves (which was standard), branding on the face (which was common), breaking up families, the forms of punishment reserved for slaves, having slaves kill one another for entertainment in the arena, the vicious abuses of the slave trade, and ultimately for the institution of slavery itself. Seneca had already seen clearly that treating slaves humanely, as 'fellow members of a household' (familiares), could have implications for the institution of slavery: 'Some may maintain that I am offering liberty to slaves in general, and toppling masters from their high estate, because I said, "they should respect their master instead of fearing him"” (Seneca, 1917, p. 311, translation slightly adapted).

St Paul's strategy is a classic Aristotelian mixed action, applied to a wounded social structure. He works for transformation 'from within' by persuading the slave-owner to accept a forward-looking obligation that alters, in practice, the workings of the institution and thereby opens, implicitly, a pathway to reform.

\section{MIXED ACTION IN THE 21ST CENTURY}

Aristotle experiments with broad applications of the concept of mixed action. As we have seen, war is a mixed action that can only be considered if there is a prospect of building peace. At times, the holding of slaves and even a money-based economy are seen through a similar lens: 
If every tool could perform its own work when ordered ... like the tripods of Hephaestus [used by the gods] ... masters would have no need of slaves.

(Politics, I.2)

The life of money-making is one undertaken under compulsion ... for it is useful for the sake of something else.

(Nicomachean Ethics I.5)

In the perspective of our planetary future, a way of life bound up with current patterns of consumption can be read as a 'mixed action' - acceptable, perhaps, because of the constraints of our situation, and because ordinary life should continue, but only to the degree that we accept a corresponding forward-looking obligation to work 'from within' to change what can be changed in the battle against carbon emissions, environmental degradation, and the loss of biodiversity.

The American economist and political thinker E. Glen Weyl (2019, p. 24) proposes a political methodology that sounds very much like mixed action:

To the maximum extent possible, erosion [of concentrations of power] should occur in ways that harness and beat existing power structures at their own game, rather than through extra-system means that could precipitate violence.

Pope Francis formulates the following principle:

Conscience ... can also recognize with sincerity and honesty what for now is the most generous response which can be given to God, and come to see with a certain moral security that it is what God himself is asking amid the concrete complexity of one's limits, while not yet fully the objective ideal.

(Amoris Laetitia, 303, 2016)

\section{LATENT POTENTIAL}

In interpreting our life-stance as a 'mixed action', we have, as it were, an alibi and a working explanation - all the more so, if we invoke the distinction between what is 'possible' here and now and 'the latent potential' that can be enabled by our actions.

The Islamic thinker Avicenna develops the powerfully enabling idea that the potential evolution of any political situation is always 
more far-reaching than what is immediately 'possible'. To use a modern example, the 'latent potential' to build aeroplanes was, in some sense, always there. But aeroplanes only became 'possible' as a result of several intervening scientific and experimental breakthroughs. The 'potential' to abolish slavery was present, or latent, in the antebellum South. How and when abolition became politically 'possible' is a matter for debate.

Ernst Bloch builds on Avicenna's observations to challenge the Aristotelian understanding of 'form' and 'potentiality' and to assert the possibility of radically new developments in which human agency can play its part (Bloch, 1952, 2019): 'Truth [is] the reflection of reality and the power to exert an influence upon reality' (quoted in Lash, 1981, p. 84).

Rabbi Jonathan Sacks (2009, pp. 231-252), from a very different perspective, explores the 'nature and significance of the future tense'. The creativity and care of God, as revealed to Moses, means that the future is open, unknowable, and full of hope. The core of Rabbi Sacks's argument is that Exodus 3:14, Ehyeh asher ehyeh, is rightly translated 'I will be what I choose to be'.

The 'evolutionary potential' of international cooperation today is difficult to gauge. What we can say with certainty is that the "possible' steps we take here and now, even steps of a procedural character, can liberate a latent evolutionary 'potential'; a better future as yet unseen can become visible for the first time.

An example of a 'possible' step that might release 'evolutionary potential' would be the systematic development of regional and inter-regional cooperation as an essential element of a decentralising multilateral order. We argue in this book that a cross-disciplinary focus on religion and human values enabled by the convening power of international organisations would represent a further seminal change, especially if accompanied by new political mechanisms to ensure 'accessibility', as we will discuss in Chapter 6. The Epilogue suggests that no region is better placed than Europe to promote these liberating intermediate steps.

In diplomacy, a clearer awareness that all governments work within non-ideal situations full of hidden potential should make it much easier to engage with others as equals, explore compromises, and decide on next steps. 'Mixed action' and 'latent potentiality' together create a conceptual space in which we can allow ourselves 
more time, making space for a gradual transition, but in which the exponents of non-moral raisons d'état will have less room to operate.

\section{OUR FIFTH AXIOM: SCANNING FOR UNSEEN JUSTICE}

\section{A SYMBIOSIS OF VALUES AND INTERESTS?}

The unexamined assumption underlying the foreign policy of many governments is that we are in a 'good place', morally speaking; that our political positioning is on the side of history; that our values and our economic interests largely converge; and (at least in many cases) that we deserve credit for offering development or humanitarian assistance to the less fortunate. To protect our interests, we invest heavily in means of enforcement (we are 'global security providers'). At the same time, we use persuasion to advance our values when persuasion works (we understand 'soft power').

Under this paradigm, the conflict that we see between values and interests occurs on a narrow front: we cooperate, as a matter of self-interest, with states that do not 'share our values'.

The UN Security Council, or in some circumstances a broad range of states acting together, might impose an arms embargo or some other measure with a view to containing a threat to international security; in that sense, situations arise in which we privilege our values over those of others. However, in the exercise of what is sometimes termed 'economic statecraft', there is a risk that the imagined symbiosis of our values and our economic interests will nurture a mindset marked by complacency. We may find it hard to look in the mirror wondering whether we too fail, whether we too end up on the wrong side of the ledger, whether we too need forgiveness for the past, whether we too are accountable to values that we find it hard to realise in practice. We may divide the world into friends and adversaries and then embrace a contradiction: seeking the good will of other governments on important issues for us, while at the same time adopting measures that, in their eyes, are deliberately harming their people. Too much of a 'double-track' approach and we lapse into a harsh, self-referential, mechanical understanding of human relationships.

The idea that our own values and interests converge and that our neighbour's values are more like a smokescreen or a matter of 
chance can amount, in the end, to withdrawing from dialogue and denying shared moral responsibility. Our fifth axiom is that discernment in the midst of opacity in accordance with a common standard should become a core value in the conduct of international relations.

\section{THE DIPLOMACY OF THE TWO STANDARDS}

In political and diplomatic situations, the formulation of alternatives is an important stage in the process of discernment. Situations are dynamic, and the future is by definition uncertain. If we are not to lapse into confusion and cross-purposes, it is useful at certain moments to enter imaginatively into the space we share with others and formulate a choice. In private life, we see this clearly: to marry or not to marry; to migrate or to stay. In 2020, confronting the risks posed by the coronavirus, public health authorities have seen that for decision-making purposes, it is helpful for the multitude of conceivable policy responses to coalesce around broad alternatives.

An important skill is to frame these key choices in such a way as to see what is mainly at stake from an ethical perspective.Very often, the way forward reflects either of two 'standards':

- on the one hand, a 'self-interested' standard that promises tangible benefits in the short term, though it may ignore some moral claims

- on the other hand, a standard more trusting of others, more in accordance with a traditional understanding of honourable conduct, more geared to the long term, more attuned to common benefits that are not easily measured

Framing our decisions as a series of choices between two standards is, in itself, an exercise of the historical imagination. In each instance, the first alternative, the 'standard of self-interest', may tempt us. An intimation of better values may cause us to hesitate.

\section{APPLYING THE STANDARD OF JUSTICE 'ADDS UP'}

Choices made in accordance with the second, more trusting standard are broadly in harmony, across time and space, with other choices made in accordance with the same standard, including other people's 
choices. The second standard - let us call it the 'standard of justice' enables us to link one situation to another and to give the future a certain shape or character, even before the detailed picture becomes clear.

We argued in Chapter 4 that when Jesus states that 'the weightier part of the law is discernment, mercy, and faith', the gift of discernment (krisis) invites us to analyse the social space that we share with others in terms of policy alternatives.

Gandhian satyagraha, or 'action in the truth', is a specific form of discernment in the midst of opacity in accordance with a common standard. Gandhi applied analogous non-violent strategies in a number of different situations: to achieve the Indian Relief Act in Natal, to oppose unjust rents in the Champaran Movement in Bihar, in a similar campaign in Gujarat, and in the Salt Satyagraha of 1930. To understand the logic of any one of these campaigns leads to a ready understanding of all the others. All have demonstrative value in a much bigger picture. In each case, it is in the long-term interests even of Gandhi's opponents to recognise the merits of his position.

The emerging policy of the EU on climate change, the 'European Green Deal', implies, in its intellectual structure, most of what we are trying to say here about 'mixed action' and the 'standard of justice'. As European citizens, 'we are proud of where we are' (von der Leyen, 2019) - yet 'where we are' is not where we need to be. Therefore, the EU is committed to an ambitious, equitable agenda of transformation. A 'just transition for all', to borrow again the language of President von der Leyen, depends on numerous individual decisions linked together by a common criterion of evaluation. This common criterion cannot be the standard of self-interest as described above. It will resemble much more the 'standard of justice'.

Scanning for the 'unseen justice' in each particular situation can help mend the principal fault line in today's global culture. That is, we can help resolve the tension between a conception of the human person as an independent, choice-making individual on the one hand, and, on the other hand, a conception of the human person that includes relationships with others, with the common good of society, and, in some sense, with the planet itself. It is overwhelmingly in our long-term interest to trust the 'standard of justice' and thereby find a sustainable point of convergence between our separate, individual interests and the overall common interest. 


\section{THE COMMON CRITERION OF HOPE}

The orientation and methodology that we promote through our six axioms aim to achieve a balance between the interweaving of different countries' interests, an interweaving which is tangible and ongoing, and the interaction of consciences, which seems to take place only at the margins of international politics. In combination, our guiding ideas imply a particular understanding of hope. Above all, our fifth axiom reflects a shared or common hope by urging us to choose justice over self-interest. Our disparate wagers on the future are similar in character, like buds on one stem.

Hope requires courage - upright action for the sake of the future. Hope is rational - an escapist fantasy does not qualify as hope in action. In his inaugural lecture as Professor of Poetry at Oxford, Seamus Heaney quotes Vaclav Havel on hope (Heaney, 1995, pp. 4-5):

a state of mind, not a state of the world ... an orientation of the spirit, of the heart; it transcends the world that is immediately experienced, and is anchored somewhere beyond its horizons ... It is not the conviction that something will turn out well, but the certainty that something makes sense, regardless of how it turns out.

Traditional religious thinkers analyse hope as the mean between presumption and despair. In Pope Benedict's encyclical on hope, 'Spe Salvi', the focus has switched from our inner equilibrium to realities outside ourselves - to 'the impossibility that the injustice of history should be the final word'.

That 'something makes sense, regardless of how it turns out', and 'the impossibility that the injustice of history should be the final word', are dynamic assertions; they imply a readiness to act, even in the face of steep odds. Hope, if restored to its full meaning in our culture, can inspire and bring together all those who face the future, determined to be 'part of the solution' - all those willing to serve under the banner of justice to bring consolation and healing to an ailing society.

In what follows, we provide a brief 'sketch' of hope, drawing on mutually reinforcing religious, literary, and philosophical sources; the 'literacy' or 'life-stance' reflected in our axioms arises naturally from 'experiments with truth' that do not depend on a specific religious understanding of the world. Nevertheless, for the believer, hope in God completes and also transforms our picture of reality. 
A story beyond this world helps us make sense of what is happening here and now. In the words of the Mahabharata: 'like a temple bell calling him out of sorrow and futility, Krishna's words rang in the morning' (Menon, 2004, p. 162).

\section{HOPE CAN BE PERCEIVED AS SOMETHING 'GIVEN'}

In his Theogony, one of the first works of Western literature, Hesiod claims a relationship with a source of truth that is both personal and of divine origin - namely the Muses encountered in the mists of Mount Helicon. Hesiod grapples with the inspiration given to him by the Muses and goes on to produce a public poetry directed towards the world of politics and society. Without the initial encounter, which is entirely 'given', Hesiod would be just another 'hungry shepherd'.

Seamus Heaney's images of the 'tidal wave' and 'cloudburst' imply the 'given-ness' of historical change. For Heaney, personal commitment and integrity are essential virtues in politics, as in writing poetry. In the end, greatness, whether in politics or poetry, is 'given', at least in part.

Below, we use the mission of Virgil's Aeneas to illustrate the communal dimension of hope. Aeneas depends at several key moments on a vision, a dream, a divine messenger. Aeneas is never self-sufficient. What he senses to be the requirements of his situation needs affirmation.

\section{HOPE PROVIDES A COMMON CRITERION OF MEASUREMENT}

Congresswoman Alexandria Ocasio-Cortez (2018) wrote an article in America magazine on criminal justice reform, beginning with a personal story flowing from the statement, 'I believe in the forgiveness of sins'. In the light of this premise, Ocasio-Cortez takes up a number of different issues in the realm of criminal justice. Then she turns again to the level of principle at which criminal justice reform converges with other projects: 'By nature, a society that forgives and rehabilitates its people is a society that forgives and transforms itself.'

To argue that a new look at imprisonment can support wider social objectives is not just about shaping coalitions. That can happen, certainly. But the point is deeper and goes to the heart of our vision in this book. As we argue above in relation to Gandhian 
satyagraha, something that they have in common links all situations in which justice and hope are at stake.

\section{HOPE AS 'GOING AGAINST THE CURRENT'}

Greek philosophers associate the virtues of hope and courage. In political decision making, as we have argued above, we are drawn towards one or other of two standards: the self-interested or the more generous option. The second option is the option of hope. Compared to the first option, it often requires exceptional courage, especially the moral courage of embarking on a journey towards an unknown destination, or a journey that will only be completed by others after our time. 'Radical hope anticipates a good for which those who have the hope as yet lack the appropriate concepts with which to understand it' (Jonathan Lear, quoted in Mittleman, 2009, p. 158). Seret arbores, qui alteri saeculo prosint ('he plants trees for the benefit of another age') (Statius, quoted by Cicero, Tusculan Disputations, XIV).

\section{HOPE ACCORDS WITH REASON}

In the Hebrew prophets, genuine hope comes with an ethical dimension and a certain kind of realism. Jeremiah opposes the wishful thinking, false optimism, and empty hope of his rival Hananiah.

A crucial aspect of the prophetic tradition is that hope can go against the current of events and yet remain reasonable. Jeremiah purchases land just as the kingdom of Judah is being overrun by the Babylonians (Jeremiah 32:13):

In their presence, I gave Baruch these instructions: 'Take these deeds, the sealed deed of purchase and its open copy, and put them in an earthenware pot, so that they may be preserved for a long time.' For Yahweh Sabaoth, the God of Israel, says this, 'People will buy fields and vineyards in this land again.'

In the Greek tradition, the classic case of a slim or forlorn hope, that at the same time is reasonable and even noble, is the Athenians' decision to abandon Athens to the Persians and stake the future of their democracy on the sea battle at Salamis. The object of our love or hope is never a matter of indifference. It is when divorced from good intentions and good judgement that hope becomes morally dangerous. 


\section{HOPE CAN BECOME A STABLE DISPOSITION}

Our fifth observation about hope is that it is better understood as a stable disposition than as an attitude or an emotion. A number of insights follow once we regard hope as a 'stable disposition'. For one thing, hope can take root as a result of repeated choices. Our understanding of hope, like our understanding of love within a relationship, can develop gradually. If hope is a disposition, it can survive our momentary lapses - as in the soliloquies of Hamlet, or when the marshal in High Noon retreats for a few moments to a dark stable. The disposition of hope can also be nurtured or revived by the sympathetic interest of others.

Hope as a 'stable disposition' begins to have an 'objective' quality; it a well-spring of action and even an intellectual resource - a radar through which to probe the darkness.

\section{HOPE IS SHARED}

In the journey of Aeneas from Troy to Latium, Virgil $(2005)^{5}$ offers us a case study in the communal dimension of hope.

Following the storm in Book I, Aeneas, for the sake of his men, 'puts on a brave face', 'simulates hope' (spem vultu simulat; Aeneid I.209). A large part of Aeneas's loyalty to the given task, his pietas, is the ability to continue to act 'as if' for the sake of others.

In Dido's Carthage, Aeneas notices images of the Trojan War painted on a wall (Aeneid I.461): Sunt lacrimae rerum ('there are tears in history'). But others' recognition of Trojan suffering, their 'com-passion' in the literal sense, touches Aeneas decisively. As a result of this communication through art, Aeneas begins to 'hope for salvation' (sperare salutem) (Aeneid I.451).

Almost the only words spoken by Aeneas to his son are these:

disce, puer, virtutem ex me verumque laborem, fortunam ex aliis.

$(X I 1.435-436)$

(From me, boy, learn courage and what work really means; good fortune, you must learn from others).

Aeneas knows that he will not live long to enjoy his marriage to Lavinia or to benefit from the arrangement he makes in Latium to settle his Trojan survivors. It is true that out of Aeneas's long struggle, 
over stages lasting hundreds of years, Rome and the Roman Empire will come to birth; the cause of Rome provides a kind of impersonal 'eschatology' in the Aeneid. But at the end of Book VI, having glimpsed the whole of reality and a glorious Roman future, Aeneas leaves the underworld by the 'ivory gate', the route by which falsa insomnia, delusive dreams, escape to the upper world (VI.896).

Aeneas does not have a perfect character; he is dependent on divine assistance. He is not blessed with happiness; nor does Roman destiny provide a secure basis for personal hope. Nevertheless, the journey from Troy to Italy is a forward-looking, communal endeavour that bears fruit; sperare salutem, the 'hope of salvation', becomes a source of meaning.

A particular feature of Aeneas's 'stable disposition' is that it is directed towards a goal that is never quite clear. A city named after himself ('Aeneadae' in Thrace) is not the right answer, nor is the 'little Troy' established by Helenus on the Greek coast. Aeneas must continue onwards towards the arva Ausonia, the 'Ausonian fields', semper cedentia retro, 'ever-receding before him' (III.496).

Abraham is prepared to live in a tent for the sake of a city he will never see. Moses wanders in the desert and dies before reaching the Promised Land. Abraham and Moses, like Aeneas, are working for others and for an unseen future. But much more than Aeneas, Abraham and Moses have a clear vocation: they are called by a God in whom they can trust absolutely and who exercises His power on humanity's behalf. 'I am with you always to the close of the age', promises the risen Jesus (Matthew 28:20).

From the perspective of religious hope, as contrasted with the dogged piety of Aeneas, life can be a joyful task that brings us closer to others. To continue working for a more just arrangement of human affairs makes complete sense, even when we fail; the meaning or pattern in events shines out in the perspective of eternity.

The Bhagavad Gita insists on the quality of an action, irrespective of results. The 'given-ness' of the fruits of action, and the confidence that somehow, somewhere the seed sown by upright action in a former generation will come to a ripening, is central to the religious perspective on human experience.

For many believers, there is something of God's grace, of mystery, even in our basic ability to live, know, and communicate. To explore the full resonance of a word like 'love' or 'hope', or, of course, to love 
another person, or hope in them, takes us to places where nothing is fully measurable, and nothing can be forced. The consolation of music or art involves a leap from shape to significance.

The 21st century needs upright and committed action at all levels of society for the sake of our future life in common. Religious hope adds light and energy to the efforts of very many people:

Do not fear, for I have redeemed you; I have called you by name, you are mine. When you pass through the sea, I will be with you; and through the rivers, they shall not overwhelm you; when you walk through fire you shall not be burned, and the flame shall not consume you.

(Isaiah 43:1-2)

The religious hope of some subtracts nothing from those others who reach out towards the future without seeking a religious explanation - or who may even remain wary, in the light of history, of crystallising human values in any broad philosophy. In this volume, we do not argue for theocracy in any form; we argue merely that to try to exclude God and religion from the conversation about our global future is to aim deliberately low.

The taking of power to ourselves, in one form or another, is at the root of the suffering of hundreds of millions of people, and poses a grave risk for humanity and for the planet. A culture of encounter founded on the humility that it takes to listen to one another, and of discernment founded on an antecedent openness to the truth of situations, can lead us to act together in hope as if a merciful God exists. This disposition - adopted for the sake of others as well as for ourselves - can become, in the French phrase, le provisoire qui dure ('the provisional that lasts'); an initial hypothesis can become the habit of hope. Here lies a viable 21st-century alternative to the 'law of the strongest' in international relations.

\section{NOTES}

I The UN Charter (including the Preamble) can be found at www.un.org> charter-united-nations.

2 The UDHR can be viewed at www.un.org>universal-declaration-humanrights.

3 The NPT can be viewed at https://www.un.org/disarmament/wmd/ nuclear/npt/. 
4 The Kreisau Circle (Der Kreisauer Kreis) became one of the most significant of the overlapping groups that opposed the Hitler regime. It is named after the von Moltke estate in Silesia where it met from I940 to I944. Its members included men and women, socialists and devout Catholics or Protestants. The Kreisau Circle studied the conditions that permitted the rise of National Socialism and explored new and creative approaches to economics, politics, and European cooperation, for implementation once Hitler was overthrown. Most of the Circle's members were discovered by the Gestapo and executed. Their ideas and their witness continue to inspire the ecumenical movement and are one of the foundations of today's European Union (Leustean, 20I4).

5 Virgil. (2005). Aeneid, translated by Stanley Lombardo. Indianapolis: Hackett Publishing Company.

\section{REFERENCES}

Aristotle. (1932). Politics, translated by H. Rackham. Loeb Classical Library. Cambridge: Harvard University Press.

Aristotle. (1935). The Athenian Constitution, The Eudemian Ethics, On Virtues and Vices, translated by H. Rackham. Loeb Classical Library. Cambridge: Harvard University Press.

Aristotle. (I972 [1925]). Nicomachean Ethics, translated with an introduction by Sir David Ross. London: Oxford University Press.

Ashdown, P. and Young, S. (2018). Nein! Standing Up to Hitler 1935-1944. London: William Collins.

Bloch, E. (20I9). Avicenna and the Aristotelian Left, translated by L. Goldman and P.Thompson. New York: Columbia Press (original German version, I952).

Bonhoeffer, D. and von Wedemeyer, M. (1994). Love Letters from Cell 92. London: Harper Collins.

Chan, J. (20I4). Confucian Perfectionism: A Political Philosophy for Modern Times. Princeton and Oxford: Princeton University Press.

Cicero. (г913). De Officiis, translated by W. Miller. Loeb Classical Library. Cambridge: Harvard University Press.

Cicero. (1927). Tusculan Disputations, translated by J.E. King. Loeb Classical Library. Cambridge: Harvard University Press.

Cooper, R. (2002). 'Why We Still Need Empires', Observer, 7 April.

Finley, M. (I980). Ancient Slavery and Modern Ideology. London: Chatto and Windus.

Garnsey, P. (I996). Ideas of Slavery from Aristotle to Angustine. Cambridge: Cambridge University Press. 
Griffin, M. (1976). Seneca: A Philosopher in Politics. Oxford: Oxford University Press.

Haass, R. (20I7). A World in Disarray: American Foreign Policy and the Crisis of the Old Order. New York: Penguin Press.

Hart, D.B. (20I7). The New Testament. New Haven and London:Yale University Press.

Heaney, S. (1995). The Redress of Poetry. London: Faber and Faber.

Lash, N. (198I). A Matter of Hope: A Theologian's Reflections on the Thought of Karl Marx. London: Darton, Longman, and Todd.

Leustean, L.N. (20I4). The Ecumenical Movement and the Making of the European Community. Oxford: Oxford University Press.

Machiavelli. (I96I). The Prince, translated with an introduction by George Bull. London: Penguin Books.

Menon, R. (2004). The Mahabharata: A Modern Rendering, Vol 2. New Delhi: Rupa \& Co.

Milbank, J. and Pabst, A. (20I6). The Politics of Virtue: Post-Liberalism and the Human Future. London: Rowman \& Littlefield International.

Mittleman, A. (2009). Hope in a Democratic Age: Philosophy, Religion, and Political Theory. Oxford: Oxford University Press.

Nyabola, N. (2018). Digital Democracy, Analogue Politics: How the Internet Era Is Transforming Kenya (African Arguments). London: Zed Books.

Ocasio-Cortez, A. (20I8). 'I Believe in the Forgiveness of Sins,' America, 27 June 2018.

Ochs, V. (2020). The Passover Haggadah: A Biography. Princeton and Oxford: Princeton University Press.

Rudd, K. (2020). 'The Coming Post-COVID Anarchy:The Pandemic Bodes Ill for Both American and Chinese Power - and for the Global Order', Foreign Affairs, May/June.

Sacks, J. (2009). Future Tense: A Vision for Jews and Judaism in the Global Culture. London. Hodder \& Stoughton.

Sen, A. (2010). The Idea of Justice. London: Penguin Books.

Seneca. (I9I7). Epistulae Morales: Letters I-LXV, with an English translation by R.M. Gummere. Loeb Classical Library. Cambridge: Harvard University Press.

Tacitus. (1967). De Vita Agricolae, edited by R.M. Ogilvie and I. Richmond. Oxford: Clarendon Press.

Thucydides. (I996). The Landmark Thucydides: A Comprehensive Guide to the Peloponnesian War (revised edition of the Richard Crawley translation), edited by R.B. Strassler. New York: Free Press.

Virgil. (I969). Vergili Opera, edited by R.A.B. Mynors. Oxford: Clarendon Press. 
Virgil. (2005). Aeneid, translated by S. Lombardo. Indianapolis: Hackett Publishing Company.

Von der Leyen, U. (2019). A Union that Strives for More: My Agenda for Europe. Political Guidelines for the Next European Commission 2019-2024. Brussels: European Commission.

Walzer, M. (1973). 'The Problem of Dirty Hands,' Philosophy \& Public Affairs, 2(2), I60-180.

Weyl, E.G. (2019). 'The Political Philosophy of RadicalxChange.' www.radicalxchange.org/blog/posts/20I9-I2-30 